\title{
Protection for Parties Involved in A Bank Credit Agreement with the Principles of Balance and Good Faith
}

\author{
M Meher ${ }^{1}$, N N Sirait ${ }^{2}$, and L Ginting ${ }^{3}$ \\ Universitas Sumatera Utara, Medan, Indonesia \\ ${ }^{1}$ montayanameher@yahoo.com
}

\begin{abstract}
An agreement has a role and function to collect and distribute funds to economic actors. A bank encounters several problems due to the conflict of interests between a debtor and a bank, as the creditor. Generally, the problem is a wanprestatie (a default) by a debtor which becomes a conflict and foreclosure of collateral by the bank. As a preventive measure, a credit agreement is made by applying the principles of balance and good faith to protect the involved parties. Hence, both a debtor and a creditor feel secure and protected from various factors that may harm their interests. The present study is a normative legal research. It analysed the implementation of the balance principle to protect the parties in a bank credit agreement based on the Circular Letter of the Financial Services Authority Number 13/SEOJK.07/2014 concerning Standard Agreement. Meanwhile, for good faith principle, in addition to its regulation set forth in Article 1338 Paragraph 3 of the Indonesian Civil Code (KitabUndang-Undang Hukum Perdata/KUH Perdata), such principle becomes one of the requirements for a legally applied agreement as stipulated by the fourth term of agreement legality as set out in Article 1320 of KUH Perdata.
\end{abstract}

Keywords: Bank, Debtor, Agreement

\section{INTRODUCTION}

A social process is a pattern of human interaction in the social groups. It can be interpreted as mutual influences amongst various aspects of life in a society. In the socio cultural life, a human interaction may generate an action in response to such interaction. Human action does not stand alone, but it is formed in an inseparable pattern of action [1]. To prevent an action of harming other individual or other group, a law and a contract should be established to prevent conflict of interests and bind people and the groups to live in order and conduct their obligations.

Generally, the term contract or agreement is sometimes interpreted ambiguously. BurgerlijkWetboek (BW) uses the term overeenkomst and contract for similar meaning. Many scholars such as Jacob Hans Niewenhuis, Hofmann, J. Satrio, SoetojoPrawirohamidjojo and MarthalenaPohan, Mariam DarusBadrulzaman, PurwahidPatrik, and Tirtodiningrat supported this understanding [2].

Subektimentioned that the term contract has a narrower meaning since it deals with a written agreement or deal than an agreement. Furthermore, Pothierdifferentiates the meaning of contract and convention (pacte). A convention (pacte) is an agreement in which two or 
more persons create, eliminate (ophenffen), or alter (wijzegen) an engagement, while a contract is an agreement that expects the implementation of an engagement [2].

Article 1233 of KUHPerdatastipulates that each engagement should be based on an agreement or a deal. When comparing an engagement with an agreement, an agreement is the source of an engagement other than the law and an engagement has an abstract definition since the parties in an engagement refer to something. An agreement has a concrete definition since the parties will conduct certain things [3].

Indonesian national development which include economic developmentfaces complex challenges in the banking sector. Since, it plays an important roleto strengthen the national economic development, there are problems arise due to various conflicts of interests between a debtor and a bank as a creditor such as a wanprestatie (a default) by a debtor which break the principles of balance and good faith.

\section{Literature Review}

\subsection{The Principle of Balance}

Balance principle can be explored from the opinions of some scholars: SutanRemiSjahdeini, Mariam DarusBadrulzaman, Sri GambirMelatiHatta, and AhmadiMiru mentioned a balance principle as an equal and balance position of the parties in making a contract or an agreement. The principle of balance requires both parties to fulfil and implement the agreement. The creditor has the power to demand an achievement and if necessary can ask for a complete repayment through the debtor's assets. However, the creditor should make an agreement in a good faith. Here, the position of a creditor is strong but it is also obligated to present a good faith to make the position of a creditor and a debtor balanced [4].

\subsection{Principle of a Good Faith}

The principle of a good faith in an agreement is set out in Article 1338 of KUHPerdata. Subekti mentioned that a good faith can be found both in the material law (a subjective understanding) and in Article 1338 paragraph (3) (an objective understanding) [5]. Ancient Roman law initially applied only a formal contract which only has a moral power, not a legal power. The obligation arising from a consensus or a deal based on iusgentium is a natural obligation; different from a civil obligation [6].There are two definitions of a good faith; firstly, proper and appropriate behavior of the two parties andsecondly, a state of not knowing any defect such as payment [6].

The willingness of the parties realized in an agreement is the basis of a binding agreement [7]. Relating to the binding obligations (pactasuntservanda), in certain circumstances, the enforcement of the obligation is limited.The principle of a good faith is set out in Article 1338 of the Indonesian Civil Code which states that agreements should be made in a good faith. This principle relates to the implementation of an agreement and applies to both the debtor and the creditor. Wirjono Prodjodikoro gives the limitation of a good faith with the term "being honest" or "honestly" [8]. Prof.M.P.L.Werry defines the meaning of a good faith means that both parties must behave based on appropriateness among the people, which means polite people without deceitfulness, deception, trickery and not being selfish, but also consider other people's interests [9]. Furthermore, aSymposium on National Civil Law held by the National Law Development Agency (BPHN) defines a good faith as(a) Honesty in making a contract 
and (b) it is highlighted that if the contract is made before an official, the parties are considered to have a good faith [9].

\section{METHOD}

The research problem is: How is the implementation of the principle of balance and good faith in protecting the parties in a bank credit agreement?

This study uses a normative legal research which analyse the Circular Letter of the Financial Services Authority Number 13/SEOJK.07/2014 concerning Standard Agreement and Article 1338 Paragraph 3 KUH Perdata [10].

\section{RESULT and DISCUSSION}

The banks give a greater attention to the low economic class or small scale business actors through a bank credit, with low interest and simple requirement. This is banking objectives of supporting the national development [8]. In realizing the objectives and ensuring a legal certainty and legal binding of the parties, standard clauses are included to protect and represent the needs of banks and business actors in a bank credit agreement.

In a bank credit agreement, the bank should implement a balance principle and a good faith principle. The creditor has the power to ask for an achievement and, if necessary, can ask for a complete repayment through the debtor's assets, but the credit or is also obliged to implement the agreement in a good faith. Here, the strong position of the credit or is balanced with an obligation to have a good faith so that the position of a creditor and a debtor is in balance. However, if the bank is the dominant party and the small scale business actor is the weak party, a balance position is difficult to be realized [8].

The implementation of the balance principle to protect the parties in a bank credit agreement has been conducted by the government through the Circular Letter of the Financial Services Authority Number 13/SEOJK.07/2014 on Standard Agreement. The circular letter instructs all funding service actors, including the bank, to incorporate the balance principle in all standard agreements. The dominant position of the bank and the weak position of the small scale business actors require a good faith in the credit agreement aiming to avoid injustice. Good faith as set forth in Article 1338 paragraph 3 of KUHPerdata should be included in an agreement based on the proper norms or what is considered appropriate in the society [8].

Meanwhile, for the good faith principle, in addition to its regulation set forth in Article 1338 paragraph 3 of KUHPerdata, such principle becomes one of the requirements for a legally binding agreement as stipulated in Article 1320 of KUHPerdata i.e. a(n) Legal Cause/Admissible Cause. A legal cause/admissible cause means that an agreement should not be contrary to laws, morals, and public order.

A credit agreement ties up two parties, the creditorsandthe debtors, where both parties are obliged to execute the agreement in a good faith. The creditors in exercising their rights must act as good creditors who do not demand more than what they are entitled to, and the debtors must also carry out their obligations appropriately. Incorporating a good faith in a credit agreementhopefully provides a legal protection from actions that possibly harm the parties.

And, if an agreement is made on a bad faith, it does not have a legal power and such agreement is null and void by the law.

\section{CONCLUSION}


The implementation of the balance principle to protect the parties in a bank credit agreement has been conducted by the government through the Circular Letter of the Financial Services Authority Number 13/SEOJK.07/2014 on Standard Agreement. The circular letter instructs all funding service business actors, including banks, to incorporate the balance principle in all standard agreements. Meanwhile, for a good faith principle, in addition to its regulation set forth in Article 1338 Paragraph 3 of KUHPerdata, such principle becomes one of the requirements for a legally binding agreement as stipulated in the fourth requirement of a legitimate agreement as set out in Article 1320 KUHPerdata i.e. a(n) Legal Cause/Admissible Cause. A good faith principle plays an important role in contract making and is a part of the legal obligation that should be fulfilled. Each party is obligated to check (onderzoekplicht) and to notify (medelingsplicht) another party before signing a contract. Thus, a good faith will get the parties to act fairly, not to make use of other party, not to harm the other, and not to use the other party to benefit themselves.

\section{REFERENCE}

[1] M. E. Setiadi and U. Kolip, Pengantar Sosiologi: Pemahaman Fakta dan Gejala Permasalahan Sosial: Teori, Aplikasi, dan Pemecahannya. Jakarta: Kencana, 2011.

[2] Agus Yudha Hernoko, Hukum Perjanjian Asas Proporsionalitas dalam Kontrak Komersil. Jakarta: Kencana, 2014.

[3] O. Setiawan, Hukum Perikatan. Jakarta: Sinar Grafika, 2018.

[4] O. C. Kaligis, Kontrak Bisnis: Teori dan Praktik Jilid 1. Bandung: Alumni, 2013.

[5] Ridwan Khairandy, Iktikad Baik dalam Kebebasan Berkontrak. Jakarta: Program Pascasarjana Fakultas Hukum Universitas Indonesia, 2004.

[6] M. D. Badrulzaman, Hukum Perikatan dalam KUHPerdata Buku Ketiga, Yurisprudensi, Doktrin, Serta Penjelasan. Bandung: Citra Aditya Bakti, 2015.

[7] Suharnoko, Hukum Perjanjian: Teori dan Analisa Kasus. Jakarta: Kencana, 2009.

[8] A. Hernoko, Hukum Perjanjian Asas. Proporsionalitas Dalam Kontrak Komersial, KencanaPrenada. Jakarta: Kencana, 2010.

[9] H. R. Daeng Naja, Hukum Kredit dan Bank Garansi. Bandung: Citra Aditya Bakti, 2005.

[10] M. P. Marzuki, Penelitian Hukum. Jakarta: KencanaPrenada Media Group, 2009. 